\title{
The physical and chemical properties of camelina (Camelina sativa (L.) Crantz) seeds subjected to sulfur fertilization
}

\author{
Ewa Ropelewska $^{1, *}$ and Krzysztof J. Jankowski ${ }^{2}$ \\ ${ }^{1}$ Fruit and Vegetable Storage and Processing Department, Research Institute of Horticulture, Konstytucji 3 Maja 1/3, \\ 96-100 Skierniewice, Poland \\ 2 Department of Agrotechnology, Agricultural Production Management and Agribusiness, Faculty of Environmental Management and \\ Agriculture, University of Warmia and Mazury in Olsztyn, M. Oczapowskiego 8, 10-719 Olsztyn, Poland
}

Received 20 April 2020 - Accepted 19 August 2020

\begin{abstract}
Camelina is an oilseed crop. Seeds may have an application in various industries. Sulfur applied to soil can increase the seed yield. However, there is insufficient information on the optimal dose of sulfur fertilization that provides the best physical and chemical properties of seed. The aim of this study was to determine the physical and chemical properties of camelina seeds subjected to sulfur fertilization at 0 (control), $15,30 \mathrm{~kg} \mathrm{Sha}^{-1}$ applied as potassium sulfate. The content of crude fat of camelina seeds ranged from $346.4 \mathrm{~g} \mathrm{~kg}^{-1} \mathrm{dm}\left(30 \mathrm{~kg} \mathrm{Sha}^{-1}\right)$ to $360.9 \mathrm{~g} \mathrm{~kg}^{-1} \mathrm{dm}$ (control plots). The selected shape factors and linear dimensions of camelina seeds were significantly positively affected by sulfur fertilizer applied at $30 \mathrm{~kg} \mathrm{Sha}^{-1}$. The results can be used to select the optimal dose of sulfur fertilizer, which has the greatest positive effect on camelina seed properties. Seeds with the best characteristics are desirable for the processing. The optimal dose of sulfur fertilizer is $30 \mathrm{~kg} \mathrm{Sha}^{-1}$. It may be useful in practice that the selected linear dimensions and shape factors of seeds were significantly positively affected by sulfur fertilizer applied at $30 \mathrm{~kg} \mathrm{Sha}^{-1}$.
\end{abstract}

Keywords: camelina seeds / sulfur fertilizer / physical properties / chemical properties

Résumé - Propriétés physiques et chimiques des graines de cameline (Camelina sativa (L.) Crantz) soumises à une fertilisation au soufre. La cameline est une plante oléagineuse. Les graines peuvent être utilisées dans diverses industries. Une fertilisation au soufre, via le sol, peut augmenter le rendement des graines. Toutefois, on ne dispose pas d'informations suffisantes sur la dose optimale de soufre qui permet d'obtenir les meilleures propriétés physiques et chimiques des semences. L'objectif de cette étude était de déterminer les propriétés physiques et chimiques des graines de cameline soumises à une fertilisation au soufre à 0 (témoin), $15,30 \mathrm{~kg} \mathrm{Sha}^{-1}$ appliquée sous forme de sulfate de potassium. La teneur brute en lipides des graines de cameline variait de $346,4 \mathrm{~g} \mathrm{~kg}^{-1} \mathrm{dm}\left(30 \mathrm{~kg} \mathrm{Sha}^{-1}\right)$ à $360,9 \mathrm{~g} \mathrm{~kg}^{-1} \mathrm{dm}$ (parcelles témoins). Les caractéristiques de forme retenues et les dimensions linéaires des graines de cameline ont été positivement influencées, et ce de manière significative, par l'engrais au soufre appliqué à $30 \mathrm{~kg} \mathrm{~S} \mathrm{ha}^{-1}$. Les résultats obtenus s'avèrent utiles pour sélectionner la dose optimale d'engrais soufré qui améliore le plus les propriétés des graines de cameline. Les graines présentant les meilleures caractéristiques sont souhaitables pour la transformation. La dose optimale d'engrais soufré est de $30 \mathrm{~kg} \mathrm{~S} \mathrm{ha}^{-1}$. Il peut être utile dans la pratique que les dimensions linéaires et les caractéristiques de forme des graines sélectionnées aient été significativement influencés positivement par l'engrais soufré appliqué à $30 \mathrm{~kg} \mathrm{Sha}{ }^{-1}$.

Mots clés : graines de cameline / engrais soufré / propriétés physiques / propriétés chimiques

*Correspondence: ewa.ropelewska@inhort.pl 


\section{Introduction}

Camelina [Camelina sativa (L.) Crantz, Brassicaceae] is a spring annual or winter annual plant, which was grown in south-eastern Europe already in the late Neolithic period (Putnam et al., 1993). Camelina was a popular oilseed crop in the European mainland and Scandinavia in the Iron Age. The species is well adapted to semi-arid climates (Mulligan, 2002). Mostly spring varieties of camelina are cultivated in Europe (Akk and Ilumae, 2005). In comparison with oilseed rape, mustard, flax and sunflower, camelina has higher drought and cold tolerance and it is characterized by lower production costs (fertilizers, pesticides) (Zubr, 1997; Lafferty et al., 2009). Its growing season is short (85-100 days) (Shukla et al., 2002). The oil content of camelina seeds can be equal to 350 $450 \mathrm{~g} \mathrm{~kg}^{-1} \mathrm{dm}$ (Zadernowski et al., 1999; Gugel and Falk, 2006; Urbaniak et al., 2008, Jiang et al., 2013; Malhi et al., 2014). Unsaturated fatty acids have a high share (85-90\%) of the total fatty acid pool in camelina oil (Zubr, 1997; Goffman et al., 1999; Zadernowski et al., 1999; Abramovic and Abram, 2005). Polyunsaturated fatty acids (PUFAs) - linoleic acid and $\alpha$-linolenic acid account for approximately $50 \%$ of total fatty acids, including $38 \%$ of $\mathrm{C}_{18: 3}$ and $15 \%$ of $\mathrm{C}_{18: 2}$ (Skjervold, 1993; Zubr, 2003). n-3 PUFAs play a key role in eye and brain development, and in cardiovascular disease prevention (Nettleton, 1991). ALA-rich diets reduce the risk of myocardial infarction, cancer and cardiovascular disease (Zubr, 2003). Due to high contents of omega-3 fatty acids and $\alpha$-linolenic acid (Ruxton et al., 2007), camelina oil can be used in food production (Pilgeram et al., 2007).

Camelina protein contains essential amino acids such as isoleucine, histidine, leucine, methionine, lysine, phenylalanine, valine and threonine. Camelina oil cake and meal are valuable feedstuffs and a rich source of fat and protein for poultry diets (Zubr, 1997). Dietary supplementation with camelina oil can increase the content of n-3 PUFAs in eggs without the unpleasant flavor typical of flaxseed oil (Rokka et al., 2002). Camelina meal has a high content of energy and protein and can be used as forage for pigs and ruminants (Matthaus and Zubr, 2000). In the vegetative and generative organs are accumulate glucosinolates (GLS) (Verkerk et al., 2009). Lošák et al. (2011) found that soil application of sulfur increased camelina seed yield by around $10 \%$. It should be noted that sulfur applied to soil increases the seed yield of Brassica crops particularly on sulfur-deficient soils (Jankowski et al., 2015). In soils characterized by moderate sulfur concentrations, sulfur fertilization exerts no yield-forming effects in camelina cultivation (Lošák et al., 2011; Solis et al., 2013; Sintim et al., 2015). Mentioned literature data indicate that sulfur fertilization can increase seed yield. However, there is insufficient information on the optimal dose of sulfur fertilization that provides the best physical and chemical properties of seed. Such information may be relevant for the storage and processing of seeds. Therefore, knowledge about the effects of sulfur fertilization on the different physical and chemical characteristics of seeds should be supplemented in order to choose the optimal dose.

The aim of this study was to determine the physical and chemical properties of camelina seeds subjected to sulfur fertilization at 0 (control), $15,30 \mathrm{~kg} \mathrm{Sha}^{-1}$ and finding out the optimal dose. The physical (thousand seed weight, densities, porosity, width, length, surface area, object boundary specific perimeter, maximum Martin radius, folding factor, mean thickness factor, compactness, roundness, Blair-Bliss coefficient) and chemical properties (crude fat content, crude protein content) of seeds were determined.

\section{Materials and methods}

\subsection{Field experiment}

Spring camelina seeds were produced in 2018, in an experiment conducted in Bałcyny $\left(\mathrm{N}=53^{\circ} 35^{\prime} 46.4^{\prime \prime}\right.$; $\left.\mathrm{E}=19^{\circ} 51^{\prime} 19.5^{\prime \prime}\right)$ at the station owned by the University of the Warmia and Mazury in Olsztyn. Before sowing, different rates of sulfur $\left(\mathrm{kg} \mathrm{ha}^{-1}\right)$ : $0,15,30$ were applied by broadcasting as potassium sulfate (samples: control, $15 \mathrm{~kg} \mathrm{~S} \mathrm{ha}^{-1}, 30 \mathrm{~kg} \mathrm{~S} \mathrm{ha}^{-1}$ ).

The experiment was carried out in three replications. Plot size of $15 \mathrm{~m}^{2}$ was used. All doses of sulfur fertilizer presented in $\mathrm{kg} \mathrm{Sha}^{-1}$ were converted into the dose per $\mathrm{m}^{2}$ and applied for the plot. The preceding crop was spring wheat. The soil was skimmed, winter plowed and mechanical loosened before presowing. The soil characteristics were detailed described by Jankowski et al. (2019). Seeds of spring camelina cv. "Omega" were sown in April. Plot seeder at a density of 450 pure live seeds $\mathrm{m}^{-2}$, to a depth of $1.0-1.5 \mathrm{~cm}$, spacing of $11 \mathrm{~cm}$ was used. $80 \mathrm{~kg} \mathrm{Nha}^{-1}$ in the form of ammonium nitrate, $45 \mathrm{~kg} \mathrm{P}_{2} \mathrm{O}_{5} \mathrm{ha}^{-1}$ as enriched superphosphate, and $90 \mathrm{~kg} \mathrm{ha}^{-1} \mathrm{~K}_{2} \mathrm{O}$ in the form of potassium sulfate and potash salt were applied immediately before sowing. $40 \mathrm{~kg} \mathrm{~N} \mathrm{ha}^{-1}$ as ammonium nitrate was applied at the beginning of inflorescence emergence of camelina. Butisan $400 \mathrm{SC}$ at $2.0 \mathrm{dm}^{3} \mathrm{ha}^{-1}$ ( $800 \mathrm{~g} \mathrm{ha}^{-1}$ metazachlor) was applied directly after sowing. Spring camelina was harvested at physiological maturity.

\subsection{Physical properties}

Thousand seed weight [g] was calculated (ISTA, 2013). Bulk density $\left[\mathrm{g} \mathrm{cm}^{-3}\right.$ ] was determined using Standard EN ISO 7971-3:2019. True density $\left[\mathrm{g} \mathrm{cm}^{-3}\right]$ was measured using Standard PN-EN 1097-6:2013 and was calculated based on the equation (1):

$$
\rho_{t}=\frac{m_{0}}{m_{0}-m_{1}} * \rho_{c}
$$

where: $\rho_{t}$-true density; $m_{0}$-seed mass in air; $m_{1}-$ seed mass in liquid; $\rho_{c}$-liquid density at a known temperature.

Porosity [\%] was calculated using the equation (2):

$$
\varepsilon=\frac{\rho_{t}-\rho_{b}}{\rho_{t}} * 100 \%,
$$

where: $\varepsilon$ is porosity, $\rho_{t}$ is true density, $\rho_{b}$ is bulk density.

The measurements of each parameter were carried out in five replicates.

\subsection{Geometric parameters}

The computer image analysis with the use of a flatbed scanner was applied to determine the geometric parameters of camelina seeds. Scaling with a caliper was performed prior to 
Table 1. Physical properties of camelina seeds subjected to sulfur fertilization.

\begin{tabular}{llll}
\hline Sample & 1000 seed weight, g & Bulk density, $\mathrm{g} \mathrm{cm}^{-3}$ & ${\text { True density, } \mathrm{g} \mathrm{cm}^{-3}}^{\text {Porosity, \% }}$ \\
\hline $0 \mathrm{~kg} \mathrm{~S} \mathrm{ha}^{-1}$ & $1.41^{\mathrm{a}}$ & $0.681^{\mathrm{a}}$ & $1.090^{\mathrm{a}}$ \\
$15 \mathrm{~kg} \mathrm{~S} \mathrm{ha}^{-1}$ & $1.42^{\mathrm{a}}$ & $0.679^{\mathrm{a}}$ & $1.085^{\mathrm{a}}$ \\
$30 \mathrm{~kg} \mathrm{~S} \mathrm{ha}^{-1}$ & $1.42^{\mathrm{a}}$ & $0.680^{\mathrm{a}}$ & $1.087^{\mathrm{a}}$ \\
\hline
\end{tabular}

$\mathrm{a}, \mathrm{b}$ denote homogeneous groups, $P \leq 0.05$.

Table 2. Linear dimensions of camelina seeds subjected to sulfur fertilization.

\begin{tabular}{lllll}
\hline Sample & $L, \mathrm{~mm}$ & $S, \mathrm{~mm}$ & $F, \mathrm{~mm}^{2}$ & $U_{g}, \mathrm{~mm}$ \\
\hline $0 \mathrm{~kg} \mathrm{~S} \mathrm{ha}^{-1}$ & $1.99^{\mathrm{a}}$ & $1.14^{\mathrm{a}}$ & $1.90^{\mathrm{a}}$ & $13.78^{\mathrm{a}}$ \\
$15 \mathrm{~kg} \mathrm{~S} \mathrm{ha}^{-1}$ & $2.01^{\mathrm{a}}$ & $1.15^{\mathrm{a}}$ & $1.92^{\mathrm{a}}$ & $13.79^{\mathrm{a}}$ \\
$30 \mathrm{~kg} \mathrm{~S} \mathrm{ha}^{-1}$ & $2.04^{\mathrm{b}}$ & $1.17^{\mathrm{b}}$ & $2.00^{\mathrm{b}}$ & $1.03^{\mathrm{a}}$ \\
\hline
\end{tabular}

a, b denote homogeneous groups, $P \leq 0.05$.

$L$ : length; $S$ : width; $F$ : surface area; $\bar{U}_{g}$ : object boundary specific perimeter; $M_{\max }$ : maximum Martin radius.

the acquisition of images. Images of seeds from plots without fertilization and with different rates of sulfur fertilizer were acquired at a resolution of $800 \mathrm{dpi}$. The images were analyzed using MaZda software (Szczypiński et al., 2009). Geometric parameters (linear dimensions and shape factors) were calculated for each seed.

\subsection{Chemical properties}

Total protein and crude fat of camelina seed were calculated. The properties of seeds were determined using the NIR Systems 6500 monochromator (FOSS NIR Systems Inc., USA) with a reflectance module. About $5 \mathrm{~g}$ of seeds were placed into a cup and scanned. The partial least squares (PLS) calibrations was used to predict the results. The reference data for total protein was from the Kjeldahl method and for crude fat from Soxhlet extraction method.

\subsection{Statistical analysis}

Statistica 12.0 (StatSoft Inc., Tulsa, USA) was used for analysis of results. The differences in the physical, geometric and chemical parameters of seeds were determined using a significance level of $P \leq 0.05$. The normality of distribution was checked using Lilliefors, Shapiro-Wilk and KolmogorovSmirnov tests, and the homogeneity of variance was determined using the Brown-Forsythe test and Levene's test. The Newman-Keuls parametric test and the Kruskal-Wallis non-parametric test were applied to analyze normally and nonnormally distributed variables, respectively.

\section{Results and discussion}

\subsection{Physical properties of camelina seeds}

The mean values of selected physical properties, such as: 1000 seed weight, bulk density, true density and porosity of camelina seeds are presented in Table 1. The 1000 seed

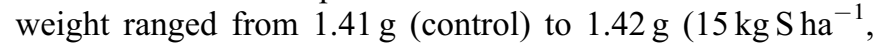

$30 \mathrm{~kg} \mathrm{~S} \mathrm{ha}^{-1}$ ). In camelina seeds, significant differences in the values of bulk and true densities density or porosity were determined between plots with and without sulfur fertilizer. All samples of camelina seeds formed another homogenous group. The bulk density of camelina seeds ranged from $0.679 \mathrm{~g} \mathrm{~cm}^{-3}$ $\left(15 \mathrm{~kg} \mathrm{Sha}^{-1}\right.$ ) to $0.681 \mathrm{~g} \mathrm{~cm}^{-3}$ (control), their true density ranged from $1.085 \mathrm{~g} \mathrm{~cm}^{-3}\left(15 \mathrm{~kg} \mathrm{Sha}^{-1}\right)$ to $1.090 \mathrm{~g} \mathrm{~cm}^{-3}$ (control) and porosity ranged from $37.4\left(15 \mathrm{~kg} \mathrm{Sha}^{-1}\right.$, $30 \mathrm{~kg} \mathrm{Sha}^{-1}$ ) to $37.5 \%$ (control). The values of the $1000 \mathrm{seed}$ weight of camelina, determined in our study, are similar to those reported by Gugel and Falk (2006) at 1.2-1.4 g, Guy et al. (2014) at 1.15-1.46 g, and Pecchia et al. (2014) at 0.98-1.56 g. Solis et al. (2013) and Lošák et al. (2011) demonstrated that sulfur fertilization had no significant effect on the 1000 seed weight of camelina. The values of bulk density of camelina seeds obtained in the current study are comparable with those reported by Guy et al. (2014) at $636-666 \mathrm{~kg} \mathrm{~m}^{-3}$. The bulk density and true density of camelina seeds are also similar to the values reported for the seeds of other oilseed plants, e.g. rapeseed with bulk density of $0.664-0.675 \mathrm{~g} \mathrm{~cm}^{-3}$ (Ropelewska et al., 2017) and $0.593-0.676 \mathrm{~g} \mathrm{~cm}^{-3}$ (Izli et al., 2009), and true density from 1.029 to $1.074 \mathrm{~g} \mathrm{~cm}^{-3}$ (Ropelewska et al., 2017), 1.015 $1.091 \mathrm{~g} \mathrm{~cm}^{-3}$ (Izli et al., 2009) or mustard with bulk density determined at $0.729-0.755 \mathrm{~g} \mathrm{~cm}^{-3}$ (Ropelewska et al., 2018) and $0.785-0.906 \mathrm{~g} \mathrm{~cm}^{-3}$ (Grewal and Singh, 2016), and true density at $1.169-1.203 \mathrm{~g} \mathrm{~cm}^{-3}$ (Ropelewska et al., 2018) and $0.924-1.275 \mathrm{~g} \mathrm{~cm}^{-3}$ (Grewal and Singh, 2016). Ropelewska and Jankowski (2020) reported that bulk density of crambe seeds was in the range of $0.619-0.625 \mathrm{~g} \mathrm{~cm}^{-3}$, and true density ranged from $0.964 \mathrm{~g} \mathrm{~cm}^{-3}$ to $0.979 \mathrm{~g} \mathrm{~cm}^{-3}$.

\subsection{Geometric properties of camelina seeds}

The values of selected linear dimensions of seeds are presented in Table 2. Sulfur fertilization resulted in the changes in the width $(S)$, length $(L)$, surface area $(F)$, object boundary specific perimeter $\left(U_{g}\right)$ and maximum Martin radius $\left(M_{\max }\right)$ of camelina seeds. In seeds, $L$ ranged from 1.99 to $2.04 \mathrm{~mm}$, 
Table 3. Shape factors of camelina seeds subjected to sulfur fertilization.

\begin{tabular}{lllll}
\hline Sample & $W_{4},-$ & $W_{5},-$ & $W_{6},-$ & $W_{13},-$ \\
\hline $0 \mathrm{~kg} \mathrm{~S} \mathrm{ha}^{-1}$ & $2.68^{\mathrm{a}}$ & $0.75^{\mathrm{a}}$ & $0.58^{\mathrm{a}}$ & $1.08^{\mathrm{a}}$ \\
$15 \mathrm{~kg} \mathrm{~S} \mathrm{ha}^{-1}$ & $2.67^{\mathrm{b}}$ & $0.75^{\mathrm{a}}$ & $0.58^{\mathrm{a}}$ & $1.07^{\mathrm{a}}$ \\
$30 \mathrm{~kg} \mathrm{~S} \mathrm{ha}^{-1}$ & $2.67^{\mathrm{ab}}$ & $0.76^{\mathrm{b}}$ & $0.57^{\mathrm{b}}$ & $1.05^{\mathrm{b}}$ \\
\hline
\end{tabular}

$\mathrm{a}, \mathrm{b}$ denote homogeneous groups, $P \leq 0.05$.

$W_{4}$ : folding factor; $W_{5}$ : mean thickness factor; $W_{6}$ : compactness; $W_{13}$ : roundness; $\mathrm{R}_{\mathrm{B}}$ : Blair-Bliss coefficient.

$S$ ranged from 1.14 to $1.17 \mathrm{~mm}, F$ ranged from 1.90 to $2.00 \mathrm{~mm}^{2}, U_{g}$ ranged from 13.78 to $14.04 \mathrm{~mm}$, and $M_{\max }$ ranged from 1.03 to $1.05 \mathrm{~mm}$. The highest $S, L, F, U_{g}$ and $M_{\max }$ were determined in the case of seeds fertilized with the $30 \mathrm{~kg} \mathrm{Sha}^{-1}$, and the lowest values of the these parameters were observed in sample without sulfur fertilizer $\left(0 \mathrm{~kg} \mathrm{~S} \mathrm{ha}^{-1}\right)$. The control seeds and the sample fertilized with $15 \mathrm{~kg} \mathrm{Sha}^{-1}$ formed a homogenous group with respect to the values of all parameters. The sample fertilized with $30 \mathrm{~kg} \mathrm{~S}^{-1}$ formed the second homogenous group. Due to their ability to biosynthesize GLS, Brassica crops have high sulfur requirements compared with non-cruciferous crops (Jankowski et al., 2015). Wysocki et al. (2013) demonstrated that the application of sulfur at $22 \mathrm{~kg} \mathrm{ha}^{-1}$ increased camelina seed yield by around 1-6\%. Jiang et al. (2013) found that sulfur fertilizer applied at $25 \mathrm{~kg} \mathrm{ha}^{-1}$ increased camelina seed yield by approximately $7 \%$. The high sulfur requirements of camelina may be the reason for the statistically significant increase in linear dimensions of seeds caused by the highest dose of sulfur fertilizer $\left(30 \mathrm{~kg} \mathrm{Sha}^{-1}\right)$ in our research.

The shape factors of camelina seeds, including folding factor $\left(W_{4}\right)$, mean thickness factor $\left(W_{5}\right)$, compactness $\left(W_{6}\right)$, roundness $\left(W_{13}\right)$ and Blair-Bliss coefficient $\left(\mathrm{R}_{\mathrm{B}}\right)$ were also calculated (Tab. 3). In seeds, the values of shape factors were as follows: $W_{4}-2.67-2.68, W_{5}-0.75-0.76, W_{6}-0.57-$ $0.58, W_{13}-1.05-1.08$, and $\mathrm{R}_{\mathrm{B}}-1.27-1.30$. The $30 \mathrm{~kg} \mathrm{~S}^{-1}$ sample was characterized by the highest mean values of $W_{5}$ and $\mathrm{R}_{\mathrm{B}}$, and the control sample had by the lowest values of these parameters. The values of the remaining parameters $\left(W_{4}\right.$, $W_{6}$ and $W_{13}$ ) were highest in the control sample and lowest in the $30 \mathrm{~kg} \mathrm{~S} \mathrm{ha}^{-1}$ sample. The control and $15 \mathrm{~kg} \mathrm{Sha}^{-1}$ samples formed one homogeneous group with respect to the values of $W_{5}, W_{6}, W_{13}$ and $\mathrm{R}_{\mathrm{B}}$.

\subsection{Chemical properties of camelina seeds}

The mean values of chemical properties, including the crude fat content and crude protein content of camelina seeds are presented in Table 4. Seeds from the control plots had the highest crude fat content $\left(360.9 \mathrm{~g} \mathrm{~kg}^{-1} \mathrm{dm}\right)$ and the lowest crude protein content $\left(255.1 \mathrm{~g} \mathrm{~kg}^{-1} \mathrm{dm}\right)$. The sample fertilized with the highest rate of sulfur $\left(30 \mathrm{~kg} \mathrm{Sha}^{-1}\right)$ had the lowest crude fat content $\left(346.4 \mathrm{~g} \mathrm{~kg}^{-1} \mathrm{dm}\right)$ and the highest crude protein content $\left(256.7 \mathrm{~g} \mathrm{~kg}^{-1} \mathrm{dm}\right)$. Lošák et al. (2011) and Obeng et al. (2016) demonstrated that sulfur fertilization did not significantly affect the chemical properties of camelina seeds, including oil content and protein content. In a study by Joshi et al. (2017), the sulfur fertilization did not cause significant changes in oil content of camelina seeds. However,
Table 4. Chemical properties of camelina seeds subjected to sulfur fertilization.

\begin{tabular}{lll}
\hline Sample & Crude fat, $\mathrm{g} \mathrm{kg}^{-1} \mathrm{DM}$ & Crude protein, $\mathrm{g} \mathrm{kg}^{-1} \mathrm{DM}$ \\
\hline $0 \mathrm{~kg} \mathrm{~S} \mathrm{ha}^{-1}$ & $360.9^{\mathrm{a}}$ & $255.1^{\mathrm{a}}$ \\
$15 \mathrm{~kg} \mathrm{~S} \mathrm{ha}^{-1}$ & $359.4^{\mathrm{a}}$ & $255.8^{\mathrm{a}}$ \\
$30 \mathrm{~kg} \mathrm{~S} \mathrm{ha}^{-1}$ & $346.4^{\mathrm{b}}$ & $256.7^{\mathrm{a}}$ \\
\hline
\end{tabular}

a, b denote homogeneous groups, $P \leq 0.05$.

Wielebski (2006) reported that sulfur fertilization may significantly decrease the crude fat content and increase the total protein content in winter oilseed rape seeds. Sulfur is important in plant nutrition and it affects nitrogen management determining the size and quality of the seed yield. Sulfur is also a component of glucosinolates and affects the amount of these substances. An increase in sulfur fertilization can also increase the content of methionine, cystine and lysine (Wielebski, 2006). Jankowski et al. (2005) revealed that the application of sulfur used during the growing season of oilseeds may result in a reduction in the crude fat content (oil content) in seeds. It may be caused by the positive effect of sulfur on the yield and the occurrence of the diluting the ingredients in an increased yield. However, the decrease in the fat content did not affect the decrease in the fat yield per 1 ha.

Research provided new knowledge on the physical and chemical properties of seed subjected to sulfur fertilization at various doses. The results supplemented information on the effect of sulfur on camelina cultivation. It has been demonstrated that in addition to increasing seed yield, sulfur fertilization can also improve seed quality. This information may be useful for the storage and processing of seeds and may have an application in various industries.

Mineral fertilization is a key agronomic operation affecting the yield and quality of crop plants. Sulfur is an essential nutrient for plants of the family Brassicaceae. Sulfur fertilizers (similarly to nitrogen fertilizers) contribute to a decrease in the oil content and an increase in the protein content of seeds in Brassica crops. The total nitrogen + sulfur fertilization level usually remains constant, regardless of the rate of sulfur fertilizer. Brassica crops are a source of both edible oil and high-protein feed (fat-free seed residues), therefore a slight modification of the proportions of sulfur and nitrogen (which does not change the total fertilization level) has no significant effect on the economic importance and uses of seeds. Due to their physical properties, camelina seeds are suitable for processing in the oleochemical industry, and the recommended 
rate of sulfur fertilizer is $30 \mathrm{~kg} \mathrm{ha}^{-1}$. In order to develop fertilizer recommendations for agricultural practice and the oilseed processing industry, further research is needed to investigate the correlation between sulfur fertilization $v s$. the physical properties and chemical composition of camelina seeds (and other Brassica crops).

\section{Conclusions}

A high amount of sulfur fertilizer increased the linear dimensions and shape factors (width, length, surface area, object boundary specific perimeter, maximum Martin radius, mean thickness factor, compactness, roundness, Blair-Bliss coefficient) of camelina seeds and reduced the crude fat amount. Sulfur fertilization did not significantly affect the 1000 seed weight, bulk and true densities or porosity of camelina seeds.

Acknowledgements. The research was financially supported by the University of Warmia and Mazury in Olsztyn (grant No.20.610.020-110) and by the Minister of Science and Higher Education (project No. 010/RID/2018/19) in the range of the program entitled "Regional Initiative of Excellence" for the years 2019-2022, amount of funding 12.000.000 PLN.

Conflict of interest. The authors declare that they have no conflicts of interest in relation to this article.

\section{References}

Abramovic H, Abram V. 2005. Physiochemical properties, composition and oxidative stability of camelina sativa oil. Food Technol Biotech 43: 63-70.

Akk E, Ilumae E. 2005. Possibilities of growing Camelina sativa in ecological cultivation. Saku, Estonia, pp. 25-35.

Goffman FD, Thies W, Velasco L. 1999. Chemo taxonomic value of tocopherols in Brassicaceae. Phytochemistry 50: 793-798.

Grewal PS, Singh AK. 2016. Moisture dependent physical and frictional properties of mustard seeds. Int J Eng Dev Res 4(4): 464-470.

Gugel RK, Falk KC. 2006. Agronomic and seed quality evaluation of Camelina sativa in western Canada. Can J Plant Sci 86: 10471058.

Guy SO, Wysocki DJ, Schillinger WF, et al. 2014. Camelina: Adaptation and performance of genotypes. Field Crops Res 155: 224-232.

International Seed Testing Association (ISTA). 2013. International rules for seed testing.

Izli N, Unal H, Sincik M. 2009. Physical and mechanical properties of rapeseed at different moisture content. Int Agrophys 23: 137-145.

Jankowski KJ, Rybacki R, Budzyński WS. 2005. Relation between fertilization and yield of oilseed rape in big area farms [in Polish: Nawożenie a plon nasion rzepaku ozimego w gospodarstwach wielkoobszarowych]. Rosliny Oleiste-Oilseed Crops XXVI: 437-450.

Jankowski KJ, Budzyński WS, Kijewski Ł, Zając T. 2015. Biomass quality of Brassica oilseed crops in response to sulfur fertilization. Agron J 107: 1377-1391.

Jankowski KJ, Sokólski M, Kordan B. 2019. Camelina: Yield and quality response to nitrogen and sulfur fertilization in Poland. Ind Crops Prod 141: 111776, 1-10.
Jiang Y, Caldwell CD, Falk KC, Lada RR, MacDonald D. 2013. Camelina yield and quality response to combined nitrogen and sulfur. Agron J 105: 1847-1852.

Joshi SK, Ahamada S, Meher LC, Agarwal A, Nasim M. 2017. Growth and yield response of camelina sativa to inorganic fertilizers and farmyard manure in hot semi-arid climate of India. Adv Plants Agric Res 7(3): 305-309.

Lafferty M, Rife C, Foster G. 2009. Spring camelina production guide//Blue sun Biodiesel. Colorado, USA.

Lošák T, Hlušek J, Martinec J, et al. 2011. Effect of combined nitrogen and sulphur fertilization on yield and qualitative parameters of Camelina sativa [L.] Crtz. (false flax). Acta Agric Scand Sect B-Soil Plant Sci 4: 313-321.

Malhi SS, Johnson EN, Hall LM, May WE, Phelps S, Nybo B. 2014. Effect of nitrogen fertilizer application on seed yield, $\mathrm{N}$ uptake, and seed quality of Camelina sativa. Can J Soil Sci 94: 35-47.

Matthaus B, Zubr J. 2000. Variability of specific components in Camelina sativa oilseed cakes. Ind Crops Prod 12: 9-18.

Mulligan GA. 2002. Weedy introduced mustards (Brassicaceae) of Canada. Can Field Nat 116: 623-631.

Nettleton JA. 1991. Omega-3 fatty acids: Comparison of plant and seafood sources in human nutrition. J Am Diet Assoc 91: 331-337.

Obeng E, Obour A, Nelson NO. 2016. Nitrogen and sulfur fertilization effects on Camelina sativa in West Central Kansas. Kansas Agric Exper Station Res Rep 2(6): 1-5.

Pecchia P, Russo R, Brambilla I, Reggiani R, Mapelli S. 2014. Biochemical seed traits of Camelina sativa - An emerging oilseed crop for biofuel: Environmental and genetic influences. J Crop Improv 28: 465-483.

Pilgeram AL, Sands DC, Boss D, et al. 2007. Camelina sativa, a Montana omega-3 and fuel crop. In: Janick J, Whipkey A, eds. Issues in new crops and new uses. Alexandria: ASHS Press, pp. 129-131.

Putnam DH, Budin JT, Field LA, Breene WM. 1993. Camelina: a promising low-input oilseed. In: Janick J, Whipkey A, eds. New crops. New York: Wiley, pp. 314-322.

Rokka T, Alen K, Valaja J, Ryhanen EL. 2002. The effect of a Camelina sativa enriched diet on the composition and sensory quality of hen eggs. Food Res Int 35: 253-256.

Ropelewska E, Jankowski KJ. 2020. Effect of sulfur fertilization on the physical and chemical properties of crambe (Crambe abyssinica Hochst ex R.E. Fries) seeds. OCL 27(18): 1-5.

Ropelewska E, Zapotoczny P, Budzyński WS, Jankowski KJ. 2017. Discriminating power of selected physical properties of seeds of various rapeseed (Brassica napus L.) cultivars. J Cereal Sci 73: 62-67.

Ropelewska E, Jankowski KJ, Zapotoczny P, Bogucka B. 2018. Thermophysical and chemical properties of seeds of traditional and double low cultivars of white mustard. Zemdirbyste Agric 105 (3): $257-264$.

Ruxton CHS, Reed SC, Simpson MJA, Millington KJ. 2007. The health benefits of omega-3 polyunsaturated fatty acids: a review of the evidence. J Hum Nutr Diet 20: 275-285.

Shukla VKS, Dutt PC, Artz WE. 2002. Camelina oil and its unusual cholesterol content. J Am Oil Chem Soc 79: 965-969.

Sintim HY, Zheljazkov VD, Obour AK, Garcia AG, Foulke TK. 2015. Influence of nitrogen and sulfur application on camelina performance under dryland conditions. Ind Crops Prod 70: 253-259.

Skjervold H. 1993. Lifestyle diseases and human diet. In: Abstracts to Minisymposium-Lifestyle Diseases and the Human Diet-A Challenge to Future Food Production, National Institute of Animal Science, Denmark, 16-19 August, Aarhus, Denmark. 
Solis A, Vidal I, Paulino L, Johnson BL, Berti MT. 2013. Camelina seed yield response to nitrogen, sulfur, and phosphorus fertilizer in south central Chile. Ind Crops Prod 44: 132-138.

Szczypiński PM, Strzelecki M, Materka A, Klepaczko A. 2009. $\mathrm{MaZda}-\mathrm{A}$ software package for image texture analysis. Comp Meth Prog Bio 94(1): 66-76.

Urbaniak SD, Caldwell CD, Zheljazkov VD, Lada R, Luan L. 2008. The effect of cultivar and applied nitrogen on the performance of Camelina sativa L. in the Maritime Provinces of Canada. Can J Plant Sci 88: 111-119.

Verkerk R, Schreiner M, Krumbein A, Ciska E, Holst B, Rowland I. 2009. Glucosinolates in Brassica vegetables: The influence of the food supply chain on intake, bioavailability and human health. Mol Nutr Food Res 53: 219-265.

Wielebski F. 2006. Sulphur fertilization of different types of winter oilseed rape varieties in various soil conditions II. Effect on quality and chemical composition of seeds [in Polish: Nawożenie różnych typów odmian rzepaku ozimego siarką w zróżnicowanych warunkach glebowych II. Wpływ na jakosć i skład chemiczny nasion]. Ros liny Oleiste-Oilseed Crops XXVII: 283-297.

Wysocki DJ, Chastain TG, Schillinger WF, Guy SO, Karow RS. 2013. Camelina: Seed yield response to applied nitrogen and sulfur. Field Crops Res 145: 60-66.

Zadernowski R, Budzyński W, Nowak-Polakowska H, Rashed AA, Jankowski K. 1999. Effect of fertilisation on the composition of lipids from false flax (Camelina sativa L. Cr.) and crambe (Crambe abissinica Hochst.). Ros liny-Oleiste/Oilseed Crops 20: 503-510.

Zubr J. 1997. Oil-seed crop: Camelina sativa. Ind Crops Prod 6: $113-119$.

Zubr J. 2003. Dietary fatty acids and amino acids of Camelina sativa seed. J Food Qual 26: 451-462.

Cite this article as: Ropelewska E, Jankowski KJ. 2020. The physical and chemical properties of camelina (Camelina sativa (L.) Crantz) seeds subjected to sulfur fertilization. $O C L$ 27: 46. 